\title{
Emerging alveolar echinococcosis (AE) in humans and high prevalence of Echinococcus multilocularis in foxes and raccoon dogs in Lithuania
}

\author{
Mindaugas Šarkūnas ${ }^{1 *}$, Rasa Bružinskaitè ${ }^{1,4}$, Audronè Marcinkutè $^{2}$, Kęstutis Strupas $^{3}$, Vitalijus Sokolovas ${ }^{3}$, \\ Alexander Mathis ${ }^{4}$, Peter Deplazes ${ }^{4}$ \\ From Parasite infections of domestic animals in the Nordic countries - emerging threats and challenges. \\ The 22nd Symposium of the Nordic Committee for Veterinary Scientific Cooperation (NKVet) \\ Helsinki, Finland. 7-9 September 2008
}

\section{Summary}

The presence of the most important definitive and intermediate hosts suggests that conditions for the live cycle of E. multilocularis are favorable in Lithuania. While the main rodent hosts have not been investigated systematically in Lithuania, E. multilocularis has already been identified in one of 5 muskrats (Ondatra zibethicus) captured in the Šilute district. The high prevalence of E. multilocularis in red foxes and raccoon dogs as well as a notable increase of $\mathrm{AE}$ in humans document that E. multilocularis is of emerging concern in Lithuania. The human AE cases were recorded from many parts of the country suggesting that the whole territory of Lithuania should be considered as an endemic area for E. multilocularis. Considering the long prepatent period of $\mathrm{AE}$ in humans we suggest that this zoonosis is present in the area investigated for at least a few decades.

\section{Introduction}

Echinococcus multilocularis is a small tapeworm exploiting mainly wild animals with the red fox (Vulpes vulpes) being the crucial definitive host in Europe [1]. Dogs and raccoon dogs are also highly susceptible definitive hosts of E. multilocularis, while reproduction of this parasite is significantly lower in cats as shown by experimental infections [2]. Humans may get infected by uptake of eggs, and the tumor-like growth of the metacestode stage mainly in the liver may lead to a serious disease alveolar echinococcosis (AE).

\footnotetext{
* Correspondence: minsar@lva.lt

'Department of Infectious Diseases, Lithuanian Veterinary Academy, Tilžès str.

18, LT-47181, Kaunas, Lithuania

Full list of author information is available at the end of the article
}

Although a rare disease, the numbers of $\mathrm{AE}$ cases have increased in endemic areas in Central Europe [3]. AE is of considerable public health importance because of its high lethality if untreated and high treatment costs [4].

The known central-European endemic area of $E$. multilocularis has expanded during the 1990s especially to the North and East [5], and the parasite was recently reported in the Baltic and neighboring regions i.e. Poland [6], Belarus [7] and Estonia [8]. The presence of the most important definitive and intermediate hosts [9] suggests that conditions for the live cycle of E. multilocularis are therefore favorable in Lithuania. While these main rodent hosts have not been investigated systematically in Lithuania, E. multilocularis has already been identified in one of 5 muskrats (Ondatra zibethicus) captured in the Šilute district [10]. The high prevalence of E. multilocularis in red foxes and raccoon dogs as well as a notable increase of $\mathrm{AE}$ in humans was also recently documented $[11,12]$.

\section{Human infection}

In the early eighties, sporadic cases of cystic echinococcosis caused by the larval stage of E. granulosus were diagnosed in humans in Lithuania. However, during the last decades, the diagnostic techniques have improved and the incidence of human AE has risen to considerable levels, with an increasing concern among the human population and the health authorities.

From 1997 to July 2008, 96 AE cases have been diagnosed at the State Hospital for Tuberculosis and Infectious Diseases in cooperation with the Santariškiu Clinic (Vilnius University). Eighty-one percent of AE patients were farmers or persons involved in agricultural activities. 
Most of the patients (59\%) owned dogs. The AE cases were recorded from many parts of the country suggesting that the whole territory of Lithuania should be considered as an endemic area $[11,12]$.

\section{Animal infection}

The helminth fauna of carnivores from Lithuania was investigated in earlier studies, but no record was made on E. multilocularis $[13,14]$. The methods used in these studies are not well documented but the reported findings of E. granulosus as well as other small helminths in dogs and wolves indicate that E. multilocularis would most probably have been detected in the 122 foxes investigated, at least if highly prevalent at that time.

In neighboring Poland, E. multilocularis in red foxes was recorded for the first time in the Gdansk region in 1995 [6] which is close to the Lithuanian border. Interestingly, the parasite's prevalence in red foxes (35\%) in the southern part of Lithuania [11] is comparable to the one (34.5\%) reported from Poland [15]. However, based on these limited data, it remains unclear whether the East Baltic region is a newly established endemic area of an extending distribution to the eastern part of Europe, or just a hitherto unnoticed one.

In Lithuania, E. multilocularis was detected in 158 (58.7\%, 95\% CI 50.2\%-64.1\%) of 269 red foxes examined. It was present in foxes from most tested localities with the highest prevalence of $62.3 \%$ (CI $49.0-74.4 \%$ ) being observed in the Kaunas district. Mean worm burden was 1309 (1-20,924) worms per fox in this district [11]. It was found that $17 \%$ of the infected adult red foxes were harboring heavy infections ( $>1000$ worms per animal) while none of the juvenile foxes were heavily infected. This finding differs from other studies suggesting that juvenile foxes play a more important role in the life cycle of E. multilocularis [16,17]. However, our result may be biased by the low number of juvenile foxes investigated. The high prevalence $(58.7 \%)$ of E. multilocularis in red foxes in the examined areas suggests that these animals may play the most important role in the zoonotic transmission of this tapeworm in Lithuania.

The raccoon dog is a highly susceptible definitive host for E. multilocularis [2] and there are reports on infected animals from Germany [18], Poland [19] and Lithuania [11]. However, the prevalence of E. multilocularis in raccoon dogs is relatively low in these countries when compared to those of the red foxes $(2.7 \%, 8 \%$ and $10 \%$, respectively). Further, the significance of the raccoon dogs regarding the transmission of E. multilocularis to the intermediate host population is poorly understood.

In addition to the morphological detection of E. multilocularis in one of 5 muskrats (Ondatra zibethicus) captured in the Šilute district of Lithuania [10], infertile and calcified metacestodes of E. multilocularis were identified by PCR in $0.4 \%(3 / 685)$ of pigs, and 2 of 240 examined dogs $(0.8 \%)$ from the same area excreted E. multilocularis eggs [20] as characterised by multiplex PCR using primers specific for E. granulosus, E. multilocularis and Taenia spp. according to Trachsel et. al. [21].

\section{Conclusions}

The identification of AE in pigs and of E. multilocularis in dogs demonstrates that transmission of E. multilocularis is occurring in the rural environment in close vicinity to the human population. Red foxes may be considered as the most important species for transmission of E. multilocularis to humans while the respective epidemiological importance of rural dogs and raccoon dogs is still unknown and deserves further studies.

The high number of human AE cases and the high prevalence of $E$. multilocularis in definitive wild hosts as well as its presence in pigs and dogs document that E. multilocularis is of emerging concern in Lithuania. Considering the long prepatent period of $\mathrm{AE}$ in humans we suggest that this zoonosis is present in the area investigated for at least a few decades.

\section{Acknowledgments}

The study was financially supported by the Food and Agriculture Organization of the United Nations (FAO, project TCP/LIT/ 3001 (T)), the SwissBaltNet (supporter: GEBERT RÜF STIFTUNG), Lithuanian Veterinary Academy, Hospital of Tuberculosis and Infectious Diseases and Santariškiy Clinic of Vilnius University. The authors wish to thank Regina Virbaliene and Jolanta Žiliukienè, Parasitology Laboratory, National Public Health Centre, Aušrinè Barakauskienè, MD, PhD, National Centre for Pathology and Jonas Valantinas MD, PhD, Santariškiu Clinic for their valuable assistance in diagnosing human echinococcosis.

\section{Author details}

'Department of Infectious Diseases, Lithuanian Veterinary Academy, Tilžès str. 18, LT-47181, Kaunas, Lithuania. ${ }^{2}$ Clinic of Infectious Diseases, Microbiology and Dermatovenereology, Vilnius University, Lithuania. ${ }^{3}$ Santariškiu Clinic, Vilnius University, Lithuania. ${ }^{4}$ Institute of Parasitology, WHO Collaborating Centre for Parasitic Zoonoses, University of Zürich, Switzerland.

\section{Published: 13 October 2010}

\section{References}

1. Eckert J, Deplazes P: Biological, epidemiological, and clinical aspects of echinococcosis, a zoonosis of increasing concern. Clin Microbiol Rev 2004, 17:107-35.

2. Kapel CM, Torgerson PR, Thompson RC, Deplazes P: Reproductive potential of Echinococcus multilocularis in experimentally infected foxes, dogs, raccoon dogs and cats. Int J Parasitol 2006, 36:79-86.

3. Schweiger A, Ammann RW, Candinas D, Clavien PA, Eckert J, Gottstein B, Halkic N, Muellhaupt B, Prinz BM, Reichen J, Tarr PE, Torgerson PR, Deplazes P: Human alveolar ecihnococcosis after fox population increase, Switzerland. Emerg Infect Dis 2007, 13(6):878-882.

4. Torgerson PR, Schweiger A, Deplazes P, Pohar M, Reichen J, Ammann RW, Tarr PE, Halkik N, Müllhaupt B: Alveolar echinococcosis: from a deadly disease to a well-controlled infection. Relative survival and economic analysis in Switzerland over the last 35 years. J Hepatol 2008, 49(1):72-77.

5. Romig T, Dinkel A, Mackenstedt U: The present situation of echinococcosis in Europe. Parasitol Int 2006, 55:S187-191. 
6. Malczewski A, Rocki B, Ramisz A, Eckert J: Echinococcus multilocularis (Cestoda), the causative agent of alveolar echinococcosis in humans first record in Poland. J Parasitol 1995, 81:318-321.

7. Shimalov W, Shimalov VT: Helminth fauna of red fox (Vulpes vulpes Linnaeus, 1758) in southern Belarus. Parasitol Res 2003, 89:77-78.

8. Moks E, Saarma U, Valdmann H: Echinococcus multilocularis in Estonia. Emerg Infect Dis 2005, 11(12):1973-1974.

9. Prūsaitè J, Mažeikytè R, Pauža $D$, Paužienè N, Baleišis $R$, Juškaitis $R$, et al: Fauna of Lithuania. Mokslas, Vilnius 1988, (In Lithuanian).

10. Mažeika $V$, Paulauskas $A$, Balčiauskas L: New data on the helminth fauna of rodents of Lithuania. Acta Zoologica Lituanica 2003, 13:41-47.

11. Bružinskaite R: Epidemiology of Echinococcus species with reference to helminths of red foxes (Vulpes vulpes) and raccoon dogs (Nyctereutes procyonoides) in Lithuania. PhD Thesis Lithuanian Veterinary Academy, Department of Infectious Diseases 2007.

12. Bružinskaite R, Marcinkute A, Strupas K, Sokolovas V, Deplazes P, Mathis A, Eddi C, Šarkūnas M: Alveolar echinococcosis, Lithuania. Emerg Infect Dis 2007, 13(10):1618-1619.

13. Danilevičius E: Echinococcosis in Lithuanian SSR and immunodiagnosis of echinococcosis in pigs. PhD Thesis Lithuanian Veterinary Institute 1964, (in Russian).

14. Kazlauskas J, Prūsaite J: Helminths of carnivores in Lithuania. Acta Parasitologica Lituanica 1976, 12:33-40, (in Russian).

15. Gawor J, Malczewski A, Stefaniak J, Nahorski W, Paul M, Kacprzak E, et al: Risk of alveococcosis for humans in Poland. Przegl Epidemiol 2004, 58:459-465, (in Polish).

16. Tackamnn K, Loschner U, Mix H, Staubach C, Thulke HH, Conraths FJ: Spatial distribution patterns of Echinococcus multilocularis (Leucart 1863) (Cestoda: Cyclophyllidea: Taeniidae) among red foxes in an endemic focus in Branderburg, Germany. Epidemiol Infect 1998, 120:101-109.

17. Hofer S, Gloor S, Muller U, Mathis A, Hegglin D, Deplazes P: High prevalence of Echinococcus multilocularis in urban red foxes (Vulpes vulpes) and voles (Arvicola terrestris) in the city of Zurich, Switzerland. Parasitol 2000, 120:135-142.

18. Thiess A, Schuster R, Nockler K, Mix H: Helminth findings in indigenous raccoon dogs Nyctereutes procyonoides (Gray, 1834). Berliner und Munchener Tieraztlichr Wochenschrift 2001, 114:273-276, (in German).

19. Machnicka B, Dziemian E, Rocki B, Kolodziej-Sobocinska M: Detection of Echinococcus multilocularis antigens in faeces by ELISA. Parasitol Res 2003, 91:491-496.

20. Bružinskaitė R, Šarkūnas M, Torgerson PR, Mathis A, Deplazes P: Echinococcosis in pigs and intestinal infection with Echinococcus spp. in dogs in Southwestern Lithuania. Vet Parasitol .

21. Trachsel D, Deplazes $P$, Mathis A: Identification of eggs of canine Taeniids by multiplex PCR. Parasitology 2007, 134:911-920.

doi:10.1186/1751-0147-52-S1-S11

Cite this article as: Šarkūnas et al:: Emerging alveolar echinococcosis (AE) in humans and high prevalence of Echinococcus multilocularis in foxes and raccoon dogs in Lithuania. Acta Veterinaria Scandinavica 201052 (Suppl 1):S11.

\section{Submit your next manuscript to BioMed Central and take full advantage of:}

- Convenient online submission

- Thorough peer review

- No space constraints or color figure charges

- Immediate publication on acceptance

- Inclusion in PubMed, CAS, Scopus and Google Scholar

- Research which is freely available for redistribution

Submit your manuscript at www.biomedcentral.com/submit
Biomed Central 